\title{
TNF- $\alpha$ and homocysteine levels in type 1 diabetes mellitus
}

M.T. Abdel Aziz,' 'H.H. Fouad,' G.A. Mohsen,' M. Mansour ${ }^{2}$ and S. Abdel Ghaffar ${ }^{3}$

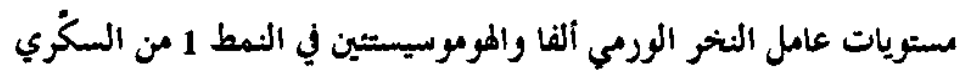

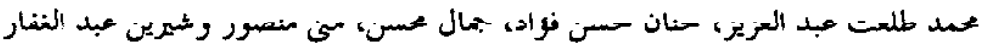

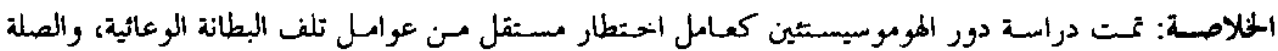

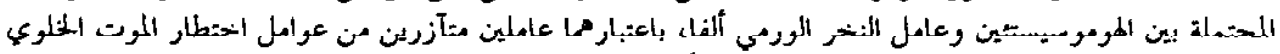

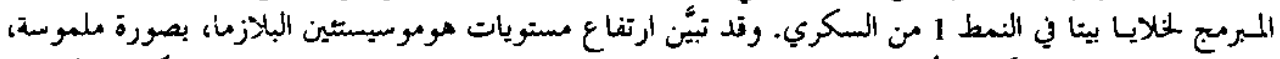

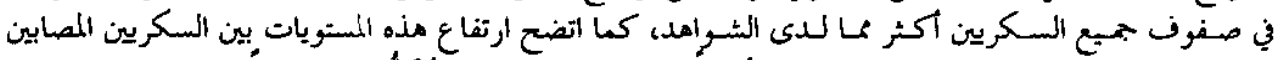

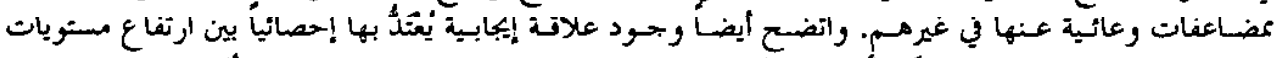

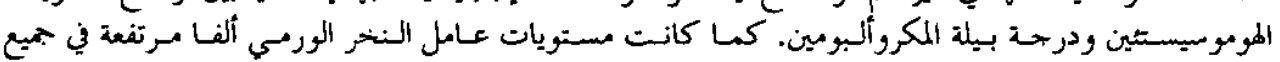

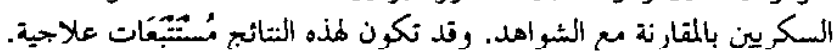

ABSTRACT The role of homocysteine as an independent risk factor for vascular endothelial damage, and the possible link between homocysteine and tumour necrosis factor-alpha (TNF- $\alpha$ ) as two synergistic risk factors for beta-cell apoptosis in type 1 diabetes mellitus was sludied. Plasma hon moysleine levels were significantly elevated in all diabetic patients compared with controls and diabetic patients with vascular complications showed higher elevations. Furthermore, homocysteine levels showed significant positive correlation with the degree of microalbuminuria. TNF-rr levels were elevated in all diabetic patients compared with controls. These results may have therapeutic implications.

Taux de TNF- $\alpha$ et d'homocystine dans le diabète sucré de type 1

RESUME Le rôle de ihomocystine en tant que facteur de risque indépendant des lésions endothéliales vasculaires, et le lien éventuel entre l'homocystine et le facteur nécrosant des tumeurs alpha (TNF- $\alpha$ ) en tant que deux facteurs de risque synergiques d'apoptose des cellules bêta dans le diabète sucré de type 1 ont éte étudiés. Les taux d'homocystine plasmatique étaient considérablement élevés chez tous les patients diabétiques par rapport aux témoins et les patients diabétiques ayant des complications vasculaires affichaient des élévations plus importantes. Par ailleurs, les taux d'homocystine montraient une corrélation positive aveo le degré de mioroalbuminurie. Les taux de JNF- $\alpha$ étaient élevés chez tous les patients diabétiques par rapport aux témoins. Ces résultats peuvent avoir des implications thérapeutiques.

'Department of Medical Biochemistry; ${ }^{2}$ Department of Internal Medicine; ${ }^{3}$ Department of Paediatrics, Faculty of Medicine. University of Cairo. Cairo. Egypt.

Received: 24/09/00; accepted: 14/01/01

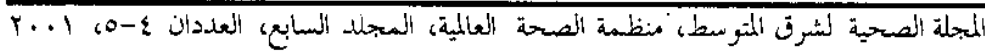




\section{Introduction}

Homocysteine (Hcy) is a sulfur-containing amino acid that accumulates in the genetic disorder homocysteinaemia as a consequence of decreased activity of enzymes involved in Hcy metabolism [I]. Human plasma contains both reduced (homocysteine) and oxidized (homocystine) species of Hcy. Disulfide forms also exist with cysteine or proteins containing reactive cysteine residues (protein-bound Hcy). The latter oxidized forms are referred to as mixed disulfides. The oxidized forms of Hcy usually comprise $98 \%-99 \%$ of total Hey in human plasma, $80 \%-90 \%$ of which is protein-bound [2]. Hcy concentration in the plasma of healthy adults ranges from $5 \mu \mathrm{mol} / \mathrm{L}$ to $15 \mu \mathrm{mol} / \mathrm{L}$ and a plasma $\mathrm{Hcy}$ concentration exceeding $15 \mu \mathrm{mol} / \mathrm{L}$ is now termed hyperhomocysteinaemia. Hyperhomocysteinaemia has been identified as an independent risk factor for atherosclerosis, including coronary artery disease. cerebrovascular disease, peripheral vascular disease and thromboembolism [3].

Progressive vascular disease of the large and small vessels is characteristic of diabetes. Microvascular complications of diabetes have a complex pathogenesis involving dysfunction of and damage to vascular endothelial cells. Vascular endothelial cells are sensitive to stimulatory factors such as increased glucose concentrations, oxidative stress and advanced glycation endproducts $\lceil 4\rceil$.

Accumulating evidence suggests that around $35 \%$ of people with type 1 diabetes mellitus have hyperhomocysteinaemia [5]. Hcy may produce vascular endothelial damage in vessels exposed to advanced glycation endproducts by several mechanisms, including induction of oxidative stress [6], impaired generation of nitric oxide $[7,8]$ and decreased anticoagulant en- dothelial properties with suppression of thrombomodulin expression in endothelial cells [9]. Thrombomodulin is predominantly expressed in vascular endothelial cells and is an important anticoagulant receptor for thrombin. A soluble form of thrombomodulin, most probably released after endothelial cell damage, is found in serum and plasma of diabetic patients and correlates with microvascular complications [ $[0]$.

It is well known that type 1 diabetes mellitus is a $\mathrm{T}$ cell-dependent autoimmunc disease resulting in selective destruction of beta cells of the islets of Langerhans with subsequent programmed cell death, i.c. apoptosis [I]]. Tumour necrosis factor-alpha (TNF- $\alpha$ ) is involved in the apoptotic pathways that are implicated in the beta-cell destruction. Ratter et al. proved that S-adenosyl-L-homocysteine potentiates TNF- $\alpha$-mediated cytotoxicity in vivo and in vitro, via blockage of the methylation of prenylated proteins in the mitochondrial membranes [12].

The aim of this work was to study the relationship between TNF $\alpha$ and Hcy in type 1 diabetic patients with and without microvascular or macrovascular complications.

\section{Methods}

Forty-tive (45) type 1 diabetic patients selected from the diabetes mellitus outpatient clinic at Abo El-Reish were recruited for this study. Fifteen (15) healthy individuals were also recruited as controls. The participants were divided into four groups:

- Group I: 15 healthy control individuals

- Group II: 15 type 1 diabetic patients without microvascular or macrovascular diabetic complications

- Group III: 15 type 1 diabetic patients with microalbuminuria 
- Group IV: 15 type 1 diabetic patients with other microvascular or macrovascular complications, such as retinopathy, neuropathy or cardiac autonomic neuropathy.

For each participant, a complete medical history was taken and clinical examination was carried out and the following parameters were evaluated: lipid profile including triglycerides (TG), cholesterol, low-density lipoprotein cholesterol (LDLC) and high-density lipoprotein-cholesterol (HDL-C) [13-16]; glycosylated haemoglobin, HbAlc [17]; microalbuminuria [18]; plasma Hcy by enzyme-linked immunoassay [19]; and plasma $T N F-\alpha$ by solid phase, two-site chemiluminescent enzymelinked immunoassay using an IMMULITE automated analyser [20].

\section{Results}

The results of the study are summarized in Table 1. There was a significant elevation of plasma Hcy levels in all the diabetic patients compared with the control group ( $P$ $<0.0001$ ). Diabetic patients with vascular complications exhibited significantly greater elevation in Hcy levels than diabetic patients without vascular complications ( $P<$ $0.0001)$. TNF- $\alpha$ was also significantly raised in all diabetic patients compared with controls $(P<0.002)$. Diabetic patients with other vascular complications were significantly older $(P<0.05)$ and had a longer duration of diabetes $(P<0.001)$ than those without vascular complications.

Diabetic patients with microalbuminuria had a longer duration of diabetes $(P<0.02)$ than those without vascular complications. There was a significant elevation of $\mathrm{HbA} 1 \mathrm{c}$ levels in all diabetic patients studied compared to controls $(P<0.0001)$. However, the difference in $\mathrm{HbAlc}$ levels in diabetic patients with vascular complications, i.e. Groups III and IV, versus diabetic patients without vascular complications, was not significant. There was a significant positive correlation between the increase in Hcy levels and the degree of microalbuminuria ( $r=0.946, P<0.001)$.

There was a non-significant correlation between Hcy levels and the age of the patients, duration of diabetes, level of $\mathrm{HbAl} \mathrm{c}$, lipid profile and TNF- $\alpha$ levels. There was a significant positive correlation between the increase in TNF- $\alpha$ levels and the elevation in HbAlc $(r=0.539, P<0.001)$, cholesterol levels $(r=0.307, P<0.05)$ and LDL-C levels $(r=0.312, P<0.05)$. In contrast, the correlations between TNF- $\alpha$ levels and age of the patients, duration of diabetes, Hcy, TG, HDL-C and the degree of microalbuminuria were not significant.

I he percentage of diabetic patients with hyperhomocysteinaemia was $88.88 \%$ (40/ 45). Among the patients with microalbuminuria, the percentage with hyperhomocysteinaemia was $86.66 \%(13 / 15)$. The proportion with hyperhomocysteinaemia among patients with other vascular complications was $100 \%(15 / 15)$, and among patients without vascular complications $73.33 \%$ (11/15). Elevated TNF- $\alpha$ levels were found in $66.66 \%$ of all diabetic patients $(30 / 45)$, in $73.33 \%(11 / 15)$ of those without microvascular complications, $66.66 \%(10 / 15)$ of those with other vascular complications and $66.66 \%(10 / 15)$ of those with microalbuminuria.

\section{Discussion}

Homocysteine is a thiol-containing amino acid. produced by intracellular demethylation of methionine. Remethylation of Hcy to methionine is catalysed by $\mathrm{B}_{12}$-dependent methionine synthase in the presence of 5- 
Table 1 Comparison of age, sex, duration of diabetes and biochemical parameters between type 1 diabetic patients with and without microvascular or macrovascular diabetic complications versus control subjects

\begin{tabular}{|c|c|c|c|c|}
\hline Variable & $\begin{array}{l}\text { Group I } \\
\text { Control }\end{array}$ & $\begin{array}{c}\text { Group II } \\
\text { Type } 1 \text { diabetic } \\
\text { subjects without } \\
\text { vascular } \\
\text { complications }\end{array}$ & $\begin{array}{c}\text { Group III } \\
\text { Type } 1 \text { diabetic } \\
\text { subjects with } \\
\text { microalbuninuria }\end{array}$ & $\begin{array}{c}\text { Group IV } \\
\text { Type } 1 \text { diabetic } \\
\text { subjects with } \\
\text { other vascular } \\
\text { complications }\end{array}$ \\
\hline No. & 15 & 15 & 15 & 15 \\
\hline $\operatorname{Sex}(M / F)$ & $8 / 7$ & $8 / 7$ & $8 / 7$ & $7 / 8$ \\
\hline Age (yoare) & $13.21 \perp 3.20$ & $13.71 \pm 4.26$ & $15.67 \pm 0.06$ & $17.7 \theta \pm 5.13^{\mathrm{ab}}$ \\
\hline $\begin{array}{l}\text { Duration of } \\
\text { diabetes (years) }\end{array}$ & - & $5.48 \pm 3.22$ & $9.03 \pm 4.43^{\mathrm{b}}$ & $12.21 \pm 5.84^{\circ}$ \\
\hline $\begin{array}{l}\text { Homocystelne } \\
\qquad(\mu \mathrm{mol} / \mathrm{L})\end{array}$ & $11.10 \pm 2.56$ & $20.10 \pm 3.24^{a}$ & $30.16 \pm 8.05^{\mathrm{a}, \mathrm{b}}$ & $27.37 \pm 2.71^{a . b}$ \\
\hline TNF- $u(\mu g /[\Pi L)$ & $0.61 \pm 1.97$ & $14.00 \pm 10.67^{\circ}$ & $17.92 \pm 21.34^{\circ}$ & $12.82 \pm 7.48^{3}$ \\
\hline $\mathrm{HbA} 1 \mathrm{c} \%$ & $6.73 \pm 0.96$ & $9.53 \pm 1.18^{\mathrm{a}}$ & $12.06 \pm 7.77^{3}$ & $12.23 \pm 7.74^{\mathrm{a}}$ \\
\hline Triglycerides (mg/dL) & $116.73 \pm 23.53$ & $129.06 \pm 24.81$ & $150.07 \pm 14.82^{a . b}$ & $127.06 \pm 26.18$ \\
\hline Cholesterol $(\mathrm{mg} / \mathrm{dL})$ & $169.33 \pm 32.17$ & $176.00 \pm 32.34$ & $192.53 \pm 27.70^{a}$ & $161.85 \pm 35.99$ \\
\hline LDL-C (mg/dL) & $106.93 \pm 26.00$ & $118.31 \pm 33.78$ & $122.98 \pm 23.06$ & $116.98 \pm 11.41$ \\
\hline HDL-C (mg/dL) & $54.13 \pm 11.63$ & $37.28 \pm 5.77 a$ & $41.16 \pm 3.07^{\mathrm{a} b}$ & $33.10 \pm 0.11$ \\
\hline $\begin{array}{l}\text { Microalbuminuria } \\
\text { ( } \mu \mathrm{g} / \mathrm{mg} \text { creatinine })\end{array}$ & & $11.33 \pm 4.29$ & $52.23 \pm 21.20^{\circ}$ & $13.12 \pm 4.19$ \\
\hline
\end{tabular}

aSignificant at $\mathrm{P}<0.05$ comparing all diabetic groups versus control group.

bSignificant at $\mathrm{P}<0.05$ comparing diabetic patients with microalbuminuria or other complications versus diabetic patients without vascular complications.

Results are expressed as mean \pm standard deviation.

TNF- $\alpha=$ tumour necrosis factor-alpha.

$L D L-C=$ low-density lipoprotein cholesterol.

$H D L-C=$ high-density lipoprotein cholesterol.

methyl-tetrahydrofolate. The latter is the product of the reduction of 5-10-mothylene-tetrahydrofolate by methylene tetrahydrofolate reductase. Homocysteine also enters the catabolic trans-sulfuration pathway, where it is converted to cysteine by two sequential enzymatic reactions catalysed by cystathionine $B$-synthase and cystathionase [2I].

Genetic defects in enzymes involved in the methylation or trans-sulfuration path- ways lead to classic homocysteinuria. Individuals with this zenetic discase have elevated plasma Hcy levels. Within the past few years several studies in vivo and in vitro have proved that hyperhomocystcinaemia induces vascular endothelial damage with subsequent atherogenic and thrombogenio cffects [22,23]. More recently, Ratter et al. reported a novel apoptogenic effect of Hcy through potentiation of TNF$\alpha$-induced cytotoxicity [12]. 
The demographic data of our study show that diabetic patients of Group IV (with other vascular complications) were older $(P<0.05)$ and had a longer duration of diabetes $(P<0.001)$ than diabetic patients without vascular complications, i.e. Group II. On the other inand, diabetic patients with microalbuminuria (Group III) had a longer duration of diabetes than those without vascular complications $(P<0.02)$, a finding consistent with the fact that vascular complications of diabetes occur after a prolonged period without adequate glycaemic control. HbAlc levels were found to be significantly elevared in all diabetic groups studied compared to controls $(P<$ 0.0001 ).

Plasma levels of Hcy were significantly elevated in most $(88.88 \%)$ of the diabetic patients whether or not they had complications. A signilicant positive conrelation was noticed between the elevation of plasma Hcy and the degree of nicroalbuminuria, whereas there was a nor-significant correlation between plasma Hcy levels and glycated proteins, lipid profile, duration of diabetes, age of the patients and TNF- $\alpha$ levels. Hyperhomocysteinaemia was more frequently found in patients with microalbuminuria: $86.6 \%$ of microalbuminuric patients compared to $73.33 \%$ of normoalbuminuric patients. These observations are in agrecment with data obtained by Ilofmann et al. [5] and Jacobsen [2I].

Several hypotheses have been proposed to cxplain the mechanisns of IIcy-induced vascular endothelial damage. Wang et al. reported that Hcy inhibited the growth of vascular endothelial cells by a mechanism involving decreased carboxymethylation of p21 $1^{\text {ras }}$ [24]. Upchurch et al. stated that Hcy decreased the expression of glutathione peroxidase and nitric oxide synthase in bovine aortic endothelial cells, with impairment of endothclium-mediated vasodilation
[25]. Furthermore, Tsai et al. proved that Hcy was mitogenic for smooth muscle cells by a mechanism involving synergistic induction of cyclin mRNA expression by serum, with subsequent accumulation of matrix proteins [20]. Apolipoprotein(a) is increased in type 1 diabetic patients with nephropathy [27] and the affinity of lipoprotein(a) for fibrin is increased by the presence of Hcy, leading to lipoprotein (a)mediated impairment of fibrinolysis and atherosclerosis [28]. Furthermore, Hcy promotes low-density lipoprotein oxidation [8].

Hcy has also been shown to stimulate collagen production in cultured aortic smooth muscle cells [29]. Jacobsen showed that Hcy upregulated the expression of the chemokine monocyte chemoattractant protein-1 in cultured human aortic endothelial cells $[2 I]$. On the other hand, Hcy oxidation products that include reactive oxygen species directly alter vascular cell functions [21].

All these effects induce atherogenesis. Hcy also has thrombogenic effects, decreasing anlicoagulant endothelial properties with suppression of thrombomodulin expression in endothelial cells [9].

Colwell [4] and Hufinans et al. [5] reported a high prevalence of hyperhomocysteinaemia in patients with type 1 diabetes mellitus. Diabetic patients with hyperhomocysteinaemia also have a significantly higher incidence of macrovascular and microvascular complications than those with normal Hcy levels. These observations agree with our data of a high incidence of macrovascular of microvascular diabetic complications among hyperhomocysteinaemic patients $(86.66 \%$ in those with microalbunninuria and $100 \%$ in those with other vascular complications), whereas only $6.66 \%$ of patients with normal lev- 
els of homocysteine have microvascular diabetic complications.

TNF- $\propto$ has been implicaled in several apoptotic pathways that are involved in the destruction of islets of Langerhans betacclls [/I]. TNF- $\alpha$-induced cytotoxicity originates in the TNF- $\alpha$ receptor- 1 (55-60 $\mathrm{kDa}$ ) signal transduction pathway, which in turn recruits caspase- 8 to the receptor complex [30,31]. Caspase- 8 is considered to play a role in the activation of other proteases that are responsible for cell death. More recently, TNF- $\alpha$-mediated cell death has also been shown to occur independently of caspase [32]. TNF- $\alpha$-induced cylotoxicity also involves the G-proteincoupled activation of phospholipase A2 [33], the generation of reactive uxygen intermediates [34] and DNA damage [35]. Moreover, it has been shown that TNF- $\alpha$ induces the opening of mitochondrial permeability transition pores resulting in dissipation of the mitochondrial transmembrane potential [36].

Several investigators have reported enhanced expression of cytokines, including TNF- $\alpha$, in both pationts and hcalthy firstdegree relatives of patients with type 1 diabetes mellitus $[20,37,38]$. These findings agree with our results showing significant elevation of TNF- $\alpha$ in $66.66 \%$ of all diabetic patients. Altered levels of TNF- $\alpha$ expression in type 1 diabctic paticnts may contribute to the insulin resistance that has been described in diabetes mellitus and a number of other disenses, including cancer, sepsis, endotoxaemia and alcoholism, and in trauma [39]. One mechanism that has been suggested for TNF- $\alpha$-induced insulin resistance is the inhibition of the insulin receptor's autophosphorylation signal and a lose of its ability to phosphorylate, on tyrosine residues, its major substrate insulin receptor substrate-1 [40]. More recently, TNF- $\alpha$ has been reported to induce scrinc phosphorylation of insulin receptor substrate- 1 which in turn prevents the insulin receptor from phosphorylating this substrate in adipocytes and hepatocytes [4I].

Furthermore, Ahmad and Goldstein reported that TNF- $\alpha$ mediates insulin resistance through modulation of expression of specific protein tyrosine phosphatase that has been implicated in the regulation of insulin receptor signalling [42]. Increased abundance of protein tyrosine phophatase modulates the action of TNF- $\alpha$ to inhibit signalling. The authors proved that TNF- $\alpha$ dose-dependently decreased ligand-stimulated autophosphorylation of insulin receptors and insulin-stimulated insulin receptor substrate- 1 phosphorylation in cultured KRC-7 and hepatoma cells. Conversely, Stephens et al. reported that TNF- $\alpha$-induced insulin resistance is accompanied by a reduction in the expression of insulin receptors $(50 \%)$, its major substrate insulin receptor substrate- $1(80 \%)$, and the insulin responsive glucose transporter GLUT 4 $(80 \%)$, without loss of insulin receptormediated signal transduction in $3 \mathrm{~T} 3$ adipocytes [39]. The different biochemical effects of TNF- $\alpha$ in different cell lines are thought to result from altered gene expression that often follows the activation of the STATS (signal transducers and activators of transcription) family of transcription factors [39].

Feugeas et al. studied the influence of metabolic and genetic factors on TNF- $\alpha$ production in type 1 diabelic patients [43]. They reported that poor glycaemic control ( $\mathrm{HbAlc}>8 \%$ ) is associated with enhanced TNF- $\alpha$ production by peripheral blood mononuclear cells. This finding concurs with our demonstration of a significant positive conclation between TNF- $\alpha$ levels and HbAlc levels $(P<0.001)$. Furthermore, Feugeas et al. found that the prescnce of the TNF- $\alpha$ ] allele in the 
microsatellite region in HLA-(DR3) subjects was associated with an increased risk of type 1 diabetes mellitus [43].

More recently, Ratter et al. showed a novel effect of the cellular methylation state on TN $\Gamma-\alpha$-mediated cytotoxicity [12]. The authors proved that S-adenosylL-homocysteine accumulates in individuals with hypcrhomocystcinacmia and as a consequence decreases the cellular methylation state, i.e. the ratio of S-adenosyl-methionine to S-adenosyl-L-homocysteine. This decrease leads to inhibition of isoprenylcysteine-carboxyl-methyl-transferase that catalyscs the carboxymethylation of C-terminal cysteine residues on isoprenylated proteins on mitochondrial membrane. This fact suggests that the methylation state of prenylated proteins is important in TNF- $\alpha$ mediated cytotoxicity. Blockage of methylation reactions was associated with enhancement of the TNF- $\alpha$-induced disruption of the mitochondrial membrane potential and inereased celi death [44].

Proteins that have C-terminal modifications include members of the RAS superfamily, such as the $\lambda$ subunit of the heterotrimeric G-binding proteins. Many of these proteins are involved in signal transduction processes. For instance, the methylated forms of certain G-binding proteins effectively activate enzymes such as phosphoinositol-3-kinase and phospholipase C$\mathrm{B}$, while their unmethylated counterparts are virtually inactive $[45,46]$. Moreover, phosphoinositol-3-kinase and phospholipase C-B are implicated in a pathway that conveys survival signals from various cell surfaces to mitochondria [47].

We conclude that the hyperhomocysteinaemia found in diabetes has two major consequences. $\Gamma$ irst, it induces vascular endothelial damage that leads to microvascular and macrovascular diabetic complications. Sccond, hyperhomocystcinacmia has a novel apoptogenic affect through potentiation of TNF- $\alpha$-induced cytotoxicity. These results may therefore have therapeutic implications. We recommend dietary supplementation with folate, vitamin $\mathrm{B}_{12}$, $\mathrm{B}_{6}$, choline or betaine at the recommended dosage for all diabetics with elevated Hcy levels $[48,49]$.

\section{References}

1. Kluijtmans LA et al. Molecular genetic analysis in mild hyperhomocysteinemia: a common mutation In the methylenetetrahydrofolate reductase gene is a genetic risk factor for cardiovascular disoaso. Amorican journal of human go netics, 1996, 58:35-41.

2. Mudd SH, Levy HL. Plasma homocyst(e)ine or homocystelne? [Letter]. New England joumal of medicine, 1995 , 333:325.

3. den Heijer $M$ et al. Hyperhomocysteinemia as a risk factor for deep vein thrombosis. New England journal of medicine, 1996, 334:759-62.
4. Colwell JA. Elevated plasma homocysteine and diabetic vascular disease. Diabetes care, 1997, 20(12):1805-6.

5. Hofmann MA et al. Hyperhomocyst(e)inemia and endothelial dysfunction in IDDM. Diabetes care, 1997, 20(12):1880-6.

6. Loscalzo J. The oxidant stress of hyperhomocyst(e)inemia. Journal of clinical investigation, 1996, 98:5-7.

7. Stamler is ot al. Advereo vascular offects of homocysteine are modulated by endothelium-derived reiaxing factor and related oxides of nitrogen. Journal of clinical investigation, 1993, 91:308-11. 
8. Stamler JS, Slivka A. Biological chemistry in thiols in the vasculature and in vasculat-related disease. Nutrition reviews, 1996, 54:1-30.

9. Nedrebo BG et al. Plasma total homocysteine levels in hyperthyroid and hypothyroid patients. Metabolism, 1998, 47(1):89-93.

10. Sernau $T$ et al. Thrombomodulin ist ein Marker für mikrovaskulare, aber nicht für makrovaskulare Endothelzellschädioung. [Thrombomodulin is a marker of microvascular, but not for macrovascular endothelial cell damage.] VASA Zeitschrift für Gefässkrankheiten, 1995, 24(4): 347-53.

11. Su $X$ et al. Significant role for Fas in the pathogenesis of autoimmune diabetes. Journal of immunology, 2000, 164(5): 2523-32.

12. Ratter $F$ ot al. Modulation of tumor nocro sis factor-alpha-mediated cytotoxicity by changes of the cellular methylation state: mechanism and in vivo relevance. International immunology, 1999, 11(4):51927.

13. Bucola G, David $H$. Duantitative detormination of serum triglycerides by the use of enzymes. Clinical chemistry, 1973, 19:476-82.

14. Allain CC et al. Enzymatic determination of total serum cholesterol. Clinical chemistry, 1974, 20:470-75.

15. Lopes-Virella MF, Stone P, Ellis S. Cholesterol determination in high-density lipoproteins separated by three different methods. Clinical chemistry, 1977, 23: 882-4.

16. Frledewala WT, Levy RI, Frearickson DS. Estimation of the concentration of LDLcholesterol in plasma, without use of the preparativo ultracentrifuge. Clinical chemistry, 1972, 18:499-502.

17. Pecoraro RE et al. Comparison of a colorimetric assay for glycosylated hemoglo- bin with ion-exchange resin chromatography. Diabetes, 1979, 28:1120-5.

18. Christenser CK, Orskov C. Rapld screening radioimmunoassay for quantification of pathological microalbuminuria. Diabotes nephropathy, 1084, 3:02 4

19. Frantzen $F$ et al. Enzyme conversion immunoassay for determining total homocysteine in plasma or serum. Cllnical chemistry, 1998, 44:311-6.

20. Ptak W et al. Macrophage function in alloxan diabetic mice: expression of adhesion molecules, generation of monokines and oxygen and NO radicals. Clinical and experimental immunofogy, $1998,114(1): 13-8$.

21. Jacobsen DW. Homocysteine and vitamins in cardiovascular disease. Clinical chemistry, 1998, 44(8):1833-43.

22. Tonstad S, Refsum HM, Ueland PM. Association between plasma total homocysteine and parental history of cardiovascular disease in children with iamillal nypercnolesterolemia. Circulation, 1997, 96(6):1803-8.

23. Rimm EB et al. Folate and vitamin B6 from diet and supplements in relation to risk of coronary heart disease among women. Journal of the American Medical Association, 1998, 279:359-64.

24. Wang $\mathrm{H}$ et al. Inhibition of growth and p2 $1^{\text {ras }}$ methylation in vascular endothelial cells by homocysteine but not cysteine. Journal of biological chemistry, 1997, 272:25380-5.

25. Upchurch Jr GR et al. Stimulation of endothelial nitric oxide production by homocyst(e)ine. Atherosclerosis, 1997 , 132:177-85.

26. Tsai JC et al. Induction of cyclin A gene expression by homocysteine in vascular smooth muscle cells. Journal of clinical investigation, 1996, 97:146-53. 
27. Tarnow $L$ et al. Increased plasma apolipoprotein(a) levels in IDDM patients with diabetic nephropathy. Diabetes care, 1996, 19:1382-7.

28. Harpel PC, Chang VT, Borth W. Homocystoine and other sulfhydryl com. pounds enhance the binding of lipoprotein (a) to fibrin: a potential biochemical link between thrombosis, atherogenesis and sulfhydryl compound metabolism. Proceedings of the National Academy of Sciences USA, 1989, 89:10193-7.

29. Majors A, Ehrhart LA, Pezacka EH. Homocysteine as a risk factor for vascular disease. Enhanced collagen production and accumulation by smooth muscle cells. Arteriosclerosis, thrombosis, and vascular biology, 1997, 17:2074-81.

30. Hsu $\mathrm{H}$ et al. TRADD-TRAF2 and TRADDFADD interactions define two distinct TNF receptor-1 signal transduction pathways. Cell, 1996, 84:299-308.

31. Nagata $S$. Apoptosis by death factor. Cell, 1997, 88:355-65.

32. Vercammen $D$ et at. Inhibition of caspases increases the sensitivity of L929 cells to necrosis mediated by TNF. Journal of experimental medicine, 1998, 187:1477-85.

33. Suffys $P$ et al. Reduced tumor necrosis factor-induced cytotoxicity by inhibitors of the arachidonic acid motabolism. Biochemical and biophysical research communications, 1987, 149:735-43.

34. Schulze-Osilholl $K$ el al. Cytotoxic activity of tumor necrosis factor-alpha is mediated by early damage of mitochondrial functions. Evidence for involvement of mitochondrial radical generation. Journal of biological chemistry, 1992 , 267:53t7-23.

35. Dealtry GB et al. DNA fragmentation and cytotoxicity caused by tumor necrosis factor is enhanced by interferon-gamma. European journal of immunology, 1987 , 17:689-93.

36. Zamzami $N$ et al. Sequential reduction of mitochondrial transmembrane potential and generation of reactive oxygen species in early programmed cell death, Journal of experimental medicine, 1995, 182:367-77.

37. Kallmann BA et al. Systemic bias of cytokine production towards cell-mediated immune regulation in IDDM and towards humoral immunity in Graves' disease. Diabetes, 1997, 46(2):237-43.

30. Hussain MJ et al. Cytokine overproduction in healthy first degree relatives of patients with IDDM. Diabetologia, 1998, $41(3): 34.3-9$

39. Stephens JM, Lee J, Pilch PF. Tumor necrosis factor-alpha-induced insulin resistance in 3T3-L1 adipooytos is accompanied by a loss of insulin receptor substrate-1 and GLUT4 expression without loss of insulin receptor-mediated signal transduction. Journal of biological chemistry, 1997, 272(2):971-6.

40. Winkler $G$ at al. Tumor necrosis faktor-alpha: az elhizas-inzulinrezisztencia-nem inzulindependens diabetes melli- tus kapcsolat lehetseges patogenetikai faktora? [Tumor necrosis factor-alpha: a possible pathogenic factor in obesity in insulin resistant and non-insulin-dependent diabetes mellitus?] Orvosi hetlap, 1998, 139(27):1627-32.

41. Shulman Gl. Cellular mechanisms of insulin resistance in humans. American joumal of cardiology, 1999, 84(1A):3J$10 \mathrm{~J}$.

42. Ahmad F, Goldstein BJ. Effect of tumor necrosis factor-alpha on the phosphorylation of tyrosine kinase receptors is associaked with dynamic alterations in specific protein-tyrosine phosphatase. 
Journal of cell biology, 1997, 64(1):11727.

43. Teugeas JP et al. Influence of melabollc and genetic factors on tumor necrosis factor-alpha and lymphotoxin-alpha production in insulin-dependent diabotes mellitus. Diabetes metabolism, 1997, 23(4):295-301.

44. Hrnoiar J et al. Vzt'ah cytokinov (TNF-alpha, $\mathrm{IL}-1$ and 6 ) and homocysteinu $k$ androidnej obezite a $k$ fenomenom syndromu inzulinovej rezistencio. [Relation between cytokines (TNF-alpha, IL-1 and 6) and homocysteine in android obesity and the phenomenon of insulin resistance syndrome.] Vnitrÿni lekarÿstvi, 1999, 45(1):11-6.

45. Hrycyna CA. Clarke S. Modification of eukaryotic signaling proteins by $\mathrm{C}$-termi- nal methylation reactions. Pharmacology and therapeutics, 1993, 59: 281300 .

46. Rando RR. Chemical biology of protein isoprenylation/methylation. Biochimica ot biophyaica aota, 1906, $1300(1): 5-10$.

47. Gajewski TF, Thompson CB. Apoptosis meets signal transduction: elimination of a BAD Influence. Cell, 1996, 87:589-92.

48. Kang SS, Wong $P W$, Norusis $M$. Homocysteinemia due to folate deficiency. Metabolism, 1987, 36:458-62.

49. Stabler SP et al. Elevation of total homocysteine in the serum of patients with cobalamin or folate deficiency detected by gas chromatography-mass spectrometry. Journal of clinical investigation, $1988,81: 466-74$.

\section{Mote from the Editor}

We wish to draw the kind attention of our potential authors to the importance of applying the editorial requirements of the EMHJ when preparing their mariusulpts for submission ror publication. Ihese provisions can be seen in the Guidelines for Authors, which are published at the end of every issue of the Journal. We regret that we are unable to accept paptis lial do not conform to the editorial requirements. 